\title{
"Nas águas turvas do penal": os fatos e a prova nos processos de responsabilização em casos de letalidade policial
}

\author{
"In the cloudy waters of the criminal law": the facts and the \\ evidence in the prosecution in cases of police lethality
}

\section{Poliana da Silva Ferreira ${ }^{1}$}

Escola de Direito de São Paulo da Fundação Getúlio Vargas - São Paulo/SP, Brasil polianasferreira@hotmail.com http://lattes.cnpq.br/0468392946703207

http://orcid.org/0000-0002-1166-7172

\begin{abstract}
Resumo: Este artigo tem por objetivo complexificar a leitura sobre a prova nos processos de responsabilização jurídica oriundos de abordagens policiais com resultado morte. Essencialmente, busca-se organizar a literatura sobre o tema e reler os dados produzidos em estudos de caso, anteriormente desenvolvidos pela autora. A análise das recentes pesquisas sobre a letalidade policial, a leitura sistemática de documentos públicos e outros insumos dos estudos de caso permitem lançar luz sobre três dimensões da prova na responsabilização de agentes de segurança pública implicados na morte de civis: a incerteza, a recursividade e a dialeticidade, categorias construídas a partir dos trabalhos de Françoise Tulkens e Michel Van de Kerchove (1998), a respeito da opacidade do direito penal e que, neste artigo, viabilizam uma compreensão dos nós que tem impossibilitado a responsabilização da polícia que mata.

PalAVRAs-Chave: letalidade policial; processo penal; prova; "autos de resistência"; impunidade.
\end{abstract}

1 Mestre e Doutoranda em Direito pela Escola de Direito de São Paulo da Fundação Getúlio Vargas. Bolsista da Fundação de Amparo à Pesquisa do Estado de São Paulo, Processo n. 2019/24756-3 FAPESP. Pesquisadora do Grupo de Pesquisa em Criminologia da Universidade do Estado da Bahia e do Núcleo de Estudos sobre o Crime e a Pena da FGV. Diretora da Plataforma Justa. Conselheira Fiscal da Rede de Estudos Empíricos em Direito- REED (2019-2021). 
ABSTRACT: This article aims to complex the reading about the evidence in the processes of legal accountability arising from police approaches resulting in death. Essentially, we seek to organize the literature on the subject and reread the data produced in case studies, previously developed by the author. The analysis of recent research on police lethality, the systematic reading of public documents and other insums of case studies allow shedding light on three dimensions of evidence in the accountability of public security agents involved in the death of civilians: uncertainty, recursion and dialecticity, categories constructed from the works of Françoise Tulkens and Michel Van De Kerchove (1998), regarding the opacity of criminal law and that, in this article, enable an understanding of the nodes that has made it impossible to hold the police that kill.

KEYWORDS: police lethality; criminal proceedings; proof; "autos de resistência"; Impunity.

SUMÁRIO: Introdução. 1. Um olhar para a superfície: reconstruindo os elos entre a letalidade policial, a impunidade e o funcionamento da justiça criminal2.O mergulho necessário: percorrendo os elos entre os fatos e os desfechos quando a polícia mata. 2.1. A prova; 2.2. Da opacidade do penal às ambiguidades do papel da prova. 3. Os atributos da prova quando a polícia mata ao longo do fluxo processual. 3.1. A incerteza intrínseca (e institucionalizada) sobre os fatos. 3.2. As hierarquias veladas. 3.3. Falsa dualidade incontornável. Considerações Finais; Referências.

\section{INTRODUÇÃO}

Este texto tem a finalidade de abordar a maneira segundo a qual desfechos absolutórios são construídos em casos de homicídios dolosos praticados por policiais militares, diante de um cenário onde movimentos sociais, ativistas antirracismo e pesquisadores/as, recorrentemente, apontam para a ausência de responsabilização de policiais envolvidos em abordagens policiais com resultado morte, no Brasil.

Absolvições sistemáticas, arquivamentos de inquéritos policiais, lavraturas dos antigos "autos de resistência", são alguns dos mecanismos lembrados pelos atores sociais acima referidos para 
materializar a ausência de punição para policiais que, eventualmente, mataram em serviço.

A impunidade, um dos mais antigos e recorrentes problemas do funcionamento do sistema de justiça, identificado por pesquisadores/as das ciências sociais e jurídicas, permanece no centro do debate público, não só quando a polícia mata. A impunidade consiste na incapacidade ou ineficiência do sistema de justiça criminal em punir, ou ainda, "[n]a desistência sistemática de aplicação de punição para quaisquer crimes, pouco importando sua natureza ou gravidade" (ADORNO, 2007, p. 132).

Estudos de fluxo de processamento criminal, publicados no Brasil desde 1988, apontam para o chamado "efeito funil" na apuração e responsabilização dos crimes, isto é,

apenas uma parcela dos indiciados e implicados em crimes e contravenções chega ao último estágio de processamento da justiça criminal, e uma proporção ainda menor é finalmente sentenciada a penas privativas de liberdade" (RIBEIRO, 2009, p. 18).

Não é demais lembrar que o efeito funil não se revela para todos os crimes, tampouco em relação a todo e qualquer acusado. Estudos recentes apontam, por exemplo, que réus negros capturados em suposto flagrante de tráfico de drogas pouco experimentam o efeito funil na justiça criminal (BOITEUX, 2009; CARDOSO; RAMOS, 2020).

Um estudo ecológico realizado por Felipe Souza e Nery Paulo Nadanovsky (2020), no qual dois índices de impunidade foram calculados a partir do número total de homicídios, apontou que, entre 2009 e 2014, todos os estados brasileiros apresentaram altos índices de impunidade. Entre as causas identificadas, são referidas de maneira frequente nas pesquisas sobre o tema, o aumento da criminalidade, a complexidade das investigações, a "morosidade da justiça" (ADORNO; PASINATO, 2007; VARGAS, 2008), além do baixo aproveitamento de dados nas relações interinstitucionais (FERRAZ, 2019). Outras possíveis causas, podem ser listadas, como a descrença da vítima no sistema, a falta de estrutura material e humana da polícia, a falta de preparo técnico e seletividade do sistema penal, o medo das testemunhas, a prescrição, dentre outras (GOMES, 2001). 
Do ponto de vista estritamente jurídico, é imperioso ressaltar que a impunidade ocorre em hipóteses de não-aplicação de uma pena a alguém formalmente condenado por praticar conduta ilícita, após a ocorrência de todos os procedimentos previstos na lei, em razão de diversos fatores. Portanto, " $[\mathrm{s}] \mathrm{e}$ o fato passa por todas as instâncias previstas e procedimentos previamente estabelecidos (pelos códigos do direito/não direito), (...) eventual absolvição não pode ser considerada um caso de impunidade" (MACHADO, 2006).

Ao lado da impunidade, o fenômeno do encarceramento em massa e da letalidade policial constituem desafios e limites à consolidação do Estado Democrático de Direito no Brasil. O que significa dizer que, mesmo apurando e responsabilizando menos do que poderia, o país segue com altas taxas de aprisionamento ${ }^{2}$, e com o emprego do uso da força letal fora de controle.

Mortes oriundas de abordagens policiais com resultado morte corresponderam a $12,8 \%$ do total de mortes violentas intencionais no país, considerando homicídios dolosos, latrocínio e lesão corporal seguida de morte, em 2020, segundo o Fórum Brasileiro de Segurança Pública (2021). Um percentual expressivo, que revela a face quantitativa do problema. Em 2020 foram 1.989 e em 2019, as mortes decorrentes de intervenção policial chegaram a 2.130. Num retrospecto recente, nota-se a persistência do problema: entre os anos de 2009 e 2016, um total de 21.892 pessoas perderam suas vidas em ações policiais (FBSP, 2017).

Entre as vítimas os "jovens-homens-negros”3 constituem as vítimas preferenciais, conforme apontado na literatura nacional (CANO, 1999, 2014; FLAUZINA, 2006; ALVES, 2011; SINHORETTO ET AL., 2014), traço que sinaliza um dos efeitos da filtragem racial na atuação policial (BARROS, 2008; DUARTE ET AL. 2014).

2 Segundo os dados do Ministério da Justiça e Segurança Pública (2020), em 1990, o país tinha 61 presos por 100 mil habitantes, nos anos 2000 passou para 137, ou seja, mais que dobrou, e em 2010 alcançou 260 presos por 100 mil habitantes. Em 2019, a população prisional chegou a 359 presos por 100 mil habitantes.

3 Expressão utilizada por Vilma Reis (2005), socióloga e ativista baiana, ao lançar luz sobre a dimensão racial, geracional e de gênero da violência estatal nos bairros periféricos de Salvador. 
Diante dos estudos sobre a responsabilização da polícia que mata, o presente artigo busca complexificar a leitura sobre a prova nos processos de responsabilização oriundos de abordagens policiais com resultado morte. Para tanto, explora-se a literatura brasileira sobre o tema, a leitura sistemática de documentos públicos e propõe-se uma releitura dos dados produzidos em estudos de caso, anteriormente desenvolvidos pela autora. Parte-se da hipótese segundo a qual a prova, sua valoração e a atuação dos agentes incumbidos de fazê-la, especificamente nos processos de responsabilização de homicídios dolosos praticados por policiais militares contra cidadãos, são fatores cruciais na determinação de desfechos não-responsabilizantes. Para aperfeiçoá-la, percorre-se os estudos já publicados sobre o tema, notadamente, no campo do Direito e das Ciências Sociais, e os insumos empíricos de estudos de caso. A análise do referido material é desenvolvida por meio dos aportes teóricos de Françoise Tulkens e Michel Van de Kerchove (1998), quando estes tratam da opacidade do direito penal, em contexto europeu.

Assim, este texto está dividido em três partes. Na primeira, revisita-se os resultados de pesquisas publicadas entre 1990 e 2020, apresentando-se os frutos de incursões na literatura brasileira, empreendidas no âmbito do projeto no qual este texto está circunscrito ${ }^{4}$. Na segunda parte, dialoga-se com a literatura especializada na produção processual da prova criminal. O objetivo da referida seção é apresentar e detalhar a hipótese já mencionada nesta introdução.

Por fim, na terceira parte, serão trabalhadas as três dimensões da prova na responsabilização de agentes de segurança pública implicados na morte de civis, identificadas a partir do arranjo teórico oferecido por Françoise Tulkens e Michel Van de Kerchove, juristas belgas que, ao se perguntarem "de onde vem a imprecisão do direito penal?" , fornecem linhas de compreensão úteis à nossa questão.

4 Projeto de doutorado: As justificativas para (não)responsabilizar a polícia que mata: olhares, discursos e representações de atores jurídico-processuais, em execução junto a Fundação de Amparo à Pesquisa do estado de São Paulo.

5 Tradução livre para: "D’où viennent les flous du droit pénal?" 
Espera-se que os esforços empreendidos neste artigo contribuam para uma melhor apreensão dos desafios que se colocam ao Estado Democrático de Direito diante dos direitos e garantias individuais e coletivos, por um lado, e para a sua própria manutenção, por outro. Além de alimentar, dogmaticamente, o conhecimento jurídico a respeito da responsabilização da polícia que mata.

\section{UM OLHAR PARA A SUPERFÍCIE: RECONSTRUINDO OS ELOS ENTRE A LETALIDADE POLICIAL, A IMPUNIDADE E O FUNCIONAMENTO DA JUSTIÇA CRIMINAL}

A atuação do poder judiciário diante de abordagens policiais com resultado morte tem sido objeto de estudos desde o final do século XX e se intensificado desde então no Brasil. Trabalhos como os de Sérgio Verani (1996) e de Cristina Neme (1999) são apontados pela literatura como precursores nos estudos sobre a relação entre uso excessivo da força pela polícia e atuação do poder judiciário. Para Sérgio Verani (1996), por exemplo, haveria uma integração harmônica entre o "aparelho repressivo-policial” e o "aparelho ideológico-jurídico" na operacionalização da legislação nos casos de mortes praticadas por policiais. Cristina Neme (1999), por sua vez, sustentou que a atuação da justiça militar estadual na apuração de homicídios dolosos contra civis praticados por policiais constituiu por muitos anos um dos mecanismos limitadores do controle da polícia, constatação feita em sua pesquisa sobre a instituição policial na ordem democrática.

Na década seguinte, nova pesquisa apontava para a ausência de responsabilização de policiais implicados em abordagens com resultado morte: "não foi encontrado um único caso em que um policial militar fosse condenado pelas mortes e ferimentos a civis, nem sequer quando existiam fortes indícios de execução como disparos à queima-roupa" (CANO; FRAGOSO, 2000, p. 231). Conclusão a que chegavam os pesquisadores Ignácio Cano e José Carlos Fragoso (2000), em pesquisa sobre a apuração de mortes praticadas pela polícia do Rio de Janeiro, entre 1993 e 1996, quando os referidos autores investigaram a atuação da Justiça Militar e indicaram que estruturas procedimentais podem favorecer a "impunidade" dos réus nesse tipo de ocorrência. 
Outros estudos publicados na primeira década dos anos 2000 (HOWLETT, 2000; AGUIAR, 2005; ADORNO; PASINATO, 2010) corroboram a sustentação da hipótese segundo a qual a justiça criminal funcionaria como uma "válvula de escape" (FERREIRA, 2019, p. 146), isto é, um instrumento que alivia momentaneamente eventuais pressões populares pela punição de policiais envolvidos em casos de violência letal, notadamente, aqueles amplamente midiatizados (FERREIRA, 2017), mas que, passado o frenesi inicial, com sua estrutura processual, é capaz de reorientar desfechos e produzir não-responsabilização como resposta plausível.

Neste sentido, "há um esprit de corps entre os operadores de Direito atuantes, tanto na Justiça Comum, quanto na Justiça Militar" (SUDBRACK, 2008, p. 124), afirma Aline Sudbrack, em estudo comparativo sobre as respostas da justiça militar e da justiça comum (júri) aos casos de violência policial letal, em Porto Alegre. Os recorrentes arquivamentos de inquéritos investigativos de mortes oriundas de intervenções policiais e até mesmo as absolvições revelam parte dos desafios à responsabilização dos agentes na justiça criminal também na região sul do país:

Proporcionalmente a Justiça Militar, até o ano de 1996, condenava mais os réus PMs do que a Justiça Comum. Não obstante, se analisarmos mais detidamente os processos existentes nesta Justiça (Militar), veremos que o maior número de condenações seria apenas relativo, levando em conta que os réus condenados são praças, na quase unanimidade dos casos (SUDBRACK, 2008, p. 225).

Como se vê, a persistente ausência de responsabilização se manteve no transcorrer dos anos em meio ao amadurecimento das instituições democráticas na nova ordem constitucional e de tensões que marcaram avanços e retrocessos no que concerne à matéria. Lembra-se por exemplo das inclusões e retiradas de conteúdos referentes a direitos humanos nos currículos dos cursos de formação de novos soldados da PM (NEME, 1999; SINHORETTO et al., 2014) e de temas afetos a desigualdades estruturais, como foi o caso da inclusão da disciplina "Ações Afirmativas e igualdade racial”, matéria incorporada à formação dos novos PMs de São Paulo em 2004 após repercussão e mobilização pública contra a abordagem policial que terminou na morte de um dentista negro em São Paulo, como bem lembrou Letícia Simões Gomes (2018). 
Neste contexto, a criação das Ouvidorias de Polícia, no final da década de 1990, em São Paulo, Rio de Janeiro e no Pará, também constituíram importante avanço (COMPARATO, 2005) após episódios de atuações policiais que se tornaram emblemáticos pelas circunstâncias que dificultavam a defesa das vítimas e pelo número de civis mortos.

Logo, embora tenha havido importantes avanços no que concerne aos processos de formação de novos policiais militares, à fiscalização da polícia e da alteração da instância de julgamento de crimes dolosos contra a vida praticados por policiais militares, fruto das mobilizações populares, o fato é que, até a segunda década do século XXI, não havia ocorrido rupturas reais de "estruturas que historicamente inviabilizaram a democratização

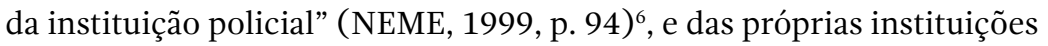
jurídicas (ZAFFALON, 2018), o que, consequentemente, pode implicar na continuidade da violência policial e da impunidade, como elementos constantes e tolerados pela sociedade civil e pelo Estado.

Já na década seguinte, a partir de 2010, o amadurecimento e o fortalecimento de mecanismos de controle e fiscalização dos atos estatais - o que inclui as instituições policiais -, especificamente nos governos Lula e Dilma com a publicação de normativas que buscavam ampliar a transparência na prestação do serviço público, contribuíram para uma relativa abertura das instituições da administração pública e do sistema de justiça para a produção e divulgação de dados públicos em geral, e especificamente, sobre segurança pública (FERREIRA, 2020). As alterações normativas e institucionais daquele contexto, repercutiram na produção de pesquisas sobre o tema, notadamente intensificando a diversificação dos objetos e das fontes de coleta de dados, o que para o campo do direito, significou também novas formas de produção e de qualificação do saber jurídico.

Em 2011, Michel Misse e sua equipe, preocupados especialmente com a performance do sistema criminal, buscaram compreender "sob uma perspectiva sociológica, como são realizados os procedimentos apuratórios e o julgamento de casos chamados de "autos de resistência”, na cidade do Rio de Janeiro. Concluíram que há uma tendência

6 Publicado no final do ano de 1999, o trabalho de Cristina Neme torna-se uma referência a partir dos anos 2000 . 
para o arquivamento dos inquéritos e dos processos instaurados para a apuração dos casos registrados sob esta rubrica, "prevalecendo a narrativa inicial apresentada pelos policiais comunicantes da ocorrência" (2011, p. 11).

Mais tarde, em 2015, Orlando Zaccone dedicou-se à investigação da atuação do Ministério Público do Rio de Janeiro. O autor analisou mais de 300 procedimentos com pedidos de arquivamento realizados pelo Ministério Público em inquéritos de homicídios provenientes de autos de resistência entre 2003 e 2009. Lançando luz sobre a atuação de outras instituições do sistema penal, Zaccone conclui que "a forma jurídica da letalidade estatal pode ser tão violenta quanto um disparo de fuzil" (ZACCONE, 2015, p. 31), indicando que além dos policiais implicados diretamente nas ocorrências, a operacionalização do direito, por outros atores, a exemplo do Ministério Público, contribui ativamente para a legitimação jurídica daquelas mortes, afinal, segundo o autor, "a polícia mata, mas não mata sozinha” (ZACCONE, 2015, p. 23).

Ainda em 2015, Maíra Machado e Marta Machado publicaram estudo sobre a responsabilização dos agentes públicos implicados no massacre do Carandiru, episódio da história de São Paulo marcado pela intervenção de policiais militares na contenção de suposta rebelião na Casa de Detenção de São Paulo, em 1992. A chacina resultou em 111 mortos e permitiu a explicitação da maneira segundo a qual "as instituições do sistema de justiça brasileiro reagiram a um episódio de grave violação de direitos humanos ocorrido no período de nossa transição à democracia” (MACHADO, 2015, p. 19). A partir destes fatos, que pareciam estar reservados no passado, as juristas buscaram "avaliar o estado atual de demandas civis e administrativas relativas ao chamado Massacre do Carandiru" (MACHADO; MACHADO; FERREIRA, 2014) e apontaram como o quadro de invisibilização das vítimas e da própria chacina foi se agravando no decorrer dos anos 2000, de modo a instaurar um cenário de indiferença e esquecimento nas instâncias judiciais. Segundo as autoras, estratégias institucionais subtraíram "uma agenda muito contemporânea de preocupações sobre o papel dos governantes, do Judiciário, da corporação policial e da sociedade civil diante da violação sistemática de direitos de cidadãos (...)" (MACHADO; MACHADO, 2015, p. 21). 
Mais recentemente, no esforço de descrever o fluxo processual de responsabilização estatal de policiais implicados em abordagens policiais com resultado morte, nas três esferas do direito, realizei estudo de caso que apontou a existência de nós institucionais que tem impedido a responsabilização da instituição Polícia, e de policiais - de maneira secundária e solitária- quando raramente esta ocorre (FERREIRA, 2019, 2021a).

Além disso, a pesquisa mostrou que o arranjo institucional adotado pelo Brasil, construído após a constituição de 1988 e aperfeiçoado pela legislação infra (anterior e posterior à $\mathrm{CF}$, de caráter federal e estadual - em São Paulo) e pelas interpretações desta, incentivam a chamada "imunização da polícia que mata", por ao menos quatro caminhos:

(i) Administrativamente, permite que o policial seja exonerado a pedido, ainda no curso do processo administrativo disciplinar - "Processo Regular", o que impede a execução de sanção decorrente das imputações referentes às violações dos direitos e deveres previstos na Lei Complementar n. 893, de 9 de março de 2001, que institui o Regulamento Disciplinar da Polícia Militar e de outras normas da instituição (FERREIRA, 2019), suscitadas pela abordagem policial com resultado morte, no âmbito do estado de São Paulo;

(ii) Legislativamente, essa blindagem da polícia resulta da ausência de lei específica que discipline o uso da força pelas polícias, crie protocolos públicos de intervenção policial em áreas urbanas e rurais - parametrizando, por um lado, todo e quaisquer usos dos instrumentos de trabalho policial, desde o uso de expressões orais no momento da abordagem ao uso da arma de fogo, e, por outro lado, a produção e o armazenamento de informações úteis ao tratamento jurídico-processual de eventuais abordagens policiais com resultado morte. Outra escolha legislativa importante decorre do fato que o "o direito brasileiro não tutela a eficiência da atuação policial como um direito coletivo, isto é, ainda não há na legislação uma proteção à eficiência da atuação policial como um valor passível de proteção por meio dos instrumentos legais já existentes” 
(FERREIRA, 2019, p. 147). Muitos desses aspectos serão retomados ao longo do presente texto.

(iii) Judicialmente, o fato de os processos criminais desenvolverem-se sob a competência do Tribunal do Júri, instância judicial formada por pessoas leigas, muitas vezes alheias aos significados institucionais da sua tomada de decisão, e sob as quais não impera o dever de justificar suas escolhas, notadamente, em função dos princípios constitucionais do "sigilo das votações", que impede a comunicabilidade dos jurados, e "soberania dos vereditos", que tem como uma das consequências a possibilidade de absolvição de réus policiais ainda que manifestamente contrária à prova dos autos, na hipótese de clemência ${ }^{7}$ dos jurados, o que inviabiliza, ao menos parcialmente, o controle social da decisão judicial.

(iv) Racialmente, refere-se aos meios através dos quais o racismo incrementa a violação dos direitos das pessoas negras, constituindo a maioria das vítimas das ocorrências de mortes decorrentes de intervenção policial. Na configuração dos processos de responsabilização, o racismo opera institucionalizado, mediado pessoalmente e internalizado (JONES, 2002). A tradução deste problema se dá quantitativamen$\mathrm{te}^{8}$ - no fato que a construção da perspectiva jurídica sobre essas mortes dá-se essencialmente pelo olhar das pessoas brancas, que historicamente ocupam a maioria dos cargos da magistratura e outros espaços decisórios de poder-,

7 Embora a clemência seja tão somente uma construção doutrinária, já que não há dispositivo legal que ampare sua existência textualmente no direito brasileiro, ela produz efeitos significativos sobre o julgamento de policiais militares implicados em processos criminais por homicídio doloso. Como bem lembra Diogo da Costa (2019), “[p]or meio da clemência, não obstante o reconhecimento da prática de ato típico, ilícito e culpável, o Estado deixa de aplicar ou determina a extinção da pena já aplicada antes do integral cumprimento" (COSTA, 2019, p. 50).

8 De acordo com dados do Conselho Nacional de Justiça e das análises da Plataforma Justa, 80,3\% das pessoas participantes da pesquisa (62,5\% das pessoas ocupantes da magistratura) se declararam brancas, o que significa que homens brancos tem 8,5 mais chances que mulheres negras de se tornarem juízes. 
e, qualitativamente - no desprezo à produção de dados institucionais que permitam a aferição dos impactos das desigualdades raciais sobre o sistema de justiça, bem como, a produção de políticas públicas para enfrentar o problema, ao que nomeio de "desracialização da informação" (FERREIRA, 2019, 2021b), um dos efeitos do que Silvio Almeida (2018) e outros autores chamam de "racismo estrutural".

O balanço da literatura especializada sinaliza, portanto, que embora existam instituições formais cujas atribuições são a apuração e a responsabilização de agentes de segurança pública implicados em abordagens policiais com resultado morte, o sistema de justiça criminal tem operado de modo a produzir ações inócuas no que diz respeito às respostas jurídico-institucionais para lidar com um problema que tem corroído o Estado de Direito no Brasil (FERREIRA, 2019). Um exemplo sintomático desse fato pode ser observado durante a audiência pública de supervisão de cumprimento de execução de sentença do caso Favela Nova Brasília vs Brasil, realizada pela Corte Interamericana de Direitos Humanos, no dia 20 de agosto de 2021, no $143^{\circ}$ Período Ordinário de Sessões, em Costa Rica ${ }^{9}$. Na ocasião, foi registrado o não cumprimento integral da sentença que declarou, em fevereiro de 2017, o Estado brasileiro responsável internacionalmente pela violação do direito às garantias judiciais de independência e imparcialidade da investigação, além da violação dos direitos à integridade pessoal de 26 homens e da integridade sexual de três mulheres, consequentes de duas operações policiais, nos anos de 1994 e 1995, na cidade do Rio de Janeiro. Na referida audiência pública, além do registro das absolvições dos réus cujo julgamento se deu 27 anos após os fatos ${ }^{10}$, foram sinalizados descumprimentos em relação a não uniformização nacional dos termos técnicos para fazer referências a esses episódios e a ausência de norma que torne o acompanhamento das

9 A audiência foi transmitida ao vivo pelo site oficial da CIDH e encontra-se disponível no Youtube, no link: https://www.youtube.com/watch?v= QBhpuJlRroE

10 Julgamento que ocorreu perante o $1^{0}$ Tribunal do Júri da capital, referente aos fatos que aconteceram apenas no ano de 1994 e que vitimou letalmente 13 pessoas. 
investigações dessas mortes pelo Ministério Público obrigatório desde o início do registro da ocorrência.

No entanto, ainda se percebe a necessidade de aprofundamento teórico no que diz respeito aos aspectos técnico-jurídicos relativos aos sentidos e limites do papel das agências do sistema de justiça, impostos por elementos estruturais, definidos a priori pelo desenho institucional. Os trabalhos analisados, por um lado, se limitaram a elaborar críticas sobre o funcionamento do sistema de justiça, a partir de categorias sociológicas, e por outro, no percurso propriamente jurídico, inviabilizaram a operacionalização do conteúdo dogmático, essência do direito, ao se confinarem ou em repetições de categorias abstratas, sem qualquer esforço de entrelaçamento entre estas e o contexto local, ou em narrativas de casos reais que, contudo, não costuram os fragmentos oferecidos pelos casos, através do direito.

Para avançar no esforço de operacionalização de categorias estritamente jurídicas, alimentado por resultados de pesquisa empírica no direito, explorarei, na próxima seção a componente que é crucial para justificar os desfechos dos processos de homicídios dolosos praticados por policial militar contra civil: a prova e sua respectiva valoração.

\section{O MERgulHo NECESSÁRIO: PERCORRENDO OS ELOS ENTRE OS FATOS E OS DESFECHOS QUANDO A POLÍCIA MATA}

Nesta seção, com o objetivo de aprofundarmos a compreensão sobre o funcionamento da justiça criminal e de construirmos uma reflexão analítica sobre o mesmo, em relação à polícia que mata, a partir do Direito, serão apresentadas as características gerais da prova, importante instituto de processo penal que tem papel decisivo na interrupção dos fluxos de responsabilização. Em seguida, exploraremos as contribuições de dois juristas estrangeiros que, a partir de um texto inscrito no campo do direito penal, fornece elementos importantes para relermos o que constitui prova e como esta é valorada no desenho institucional adotado para tratar a letalidade policial. Tomadas as devidas distâncias em relação aos contextos locais, aos campos de análise e aos objetivos das produções textuais, recuperaremos os conceitos centrais apresentados pelos autores para desenvolvermos uma reflexão original sobre o tema. 


\subsection{A PROVA}

De acordo com a doutrina brasileira, especializada em processo judicial, a prova é o meio através do qual as partes buscam demonstrar a "verdade" dos fatos, com a finalidade de convencer o juiz ou o tribunal competente a respeito da autoria e da materialidade de um crime e de outras alegações sustentadas pelas partes no curso do processo penal. Cândido Dinamarco sustenta que a "prova é um conjunto de atividades de verificação e demonstração, mediante as quais se procura chegar à verdade dos fatos relevantes para o julgamento" (DINAMARCO, 2001, p. 43).

A prova teria, assim, o objetivo de permitir a reconstrução dos fatos investigados no processo, buscando a coincidência com a "realidade histórica” (PACELLI, 2015; BRASILEIRO DE LIMA, 2020). No contexto de um Estado Democrático de Direito, a prova é um dos meios que reduz eventuais arbitrariedades de magistrados no exercício da atividade jurisdicional (MATIDA, 2009). Por isso, se diz que a prova permite ao julgador a determinação dos fatos de um determinado caso, em conformidade com preferências institucionais estabelecidas a priori (MATIDA; HERDY, 2019), ou seja, há um conjunto de normas, de comportamento, sanção e processo - nem sempre escritas -, que determinam o momento de uma dada tomada de decisão pelo órgão competente para julgar a causa. De uma maneira geral, a prova é produzida no curso de um processo e, de forma excepcional, também na fase de investigação.

Na legislação, o Código de Processo Penal determina que "Art. 155. O juiz formará sua convicção pela livre apreciação da prova produzida em contraditório judicial, não podendo fundamentar sua decisão exclusivamente nos elementos informativos colhidos na investigação, ressalvadas as provas cautelares, não repetíveis e antecipadas”.

A prova é, portanto, uma das maneiras através das quais o processo penal, desenhado abstratamente pelo constituinte e pelo legislador, é "perfurado" pela realidade. Além da prova, conceitos correlatos, como os "indícios" e as "evidências", também proporcionam encontros entre a realidade concreta e as asserções jurídicas. Muitas vezes, pré-programados, esses encontros cumprem papéis específicos e têm efeitos não declarados, a exemplo das disputas de sentido sobre um determinado fato, confronto de ideias, ideais de justiça e silenciamentos. 
Os indícios no processo penal são elementos indicativos de que um crime ocorreu. De acordo com o Código de Processo Penal, em seu art. 239, "[c] onsidera-se indício a circunstância conhecida e provada, que, tendo relação com o fato, autorize, por indução, concluir-se a existência de outra ou outras circunstâncias”, dito de maneira mais simples, são os elementos que indicam de maneira indutiva a existência de um crime, a maneira de executá-lo e/ou a autoria, conforme se depreende de uma dada circunstância, de um objeto, de uma vestimenta ou de uma narrativa.

Embora seu uso esteja restrito ao plano da probabilidade, os indícios produzem efeitos concretos no plano normativo, pois se tornam subsídios autorizativos da instauração de inquérito policial, da decretação de prisão preventiva e da pronúncia de réus nos procedimentos do tribunal do júri. Já as evidências, não dependem de qualquer complemento para se afirmarem, pois são visíveis, translúcidas, inquestionáveis. Nas palavras de Rui Costa Martins “a evidência não remete para dispositivos exteriores de avaliação, porque ela constitui um desdobramento do sentido na indicação da sua própria verdade" (2011, p. 11).

Assim, para afirmar ou negar uma assertiva a respeito de um fato perante um juízo, as partes mobilizam meios de prova, de diferentes tipos e conteúdos, que não têm hierarquias entre si, com a finalidade de convencer juízes, desembargadores, ou jurados, a depender do rito, de modo a produzir evidências ${ }^{11}$. Não se pode esquecer, que os meios de prova necessitam de valoração, ou seja, o esforço intelectual realizado por quem julga é imprescindível, o que significa que "ao julgador cabe a valoração livre da prova, sendo uma coisa assistir o ato de alguém confessar algo, ou aceitar a integração processual de determinada declaração cujo conteúdo seja de confissão, outra crê-la confiável" (MATIDA, 2009, p. 62), a prova precisa ser interpretada pelo juízo, cuja conclusão sobre esta deve ser, em regra, explicitada na decisão judicial.

No Direito brasileiro, são admitidos como meios de prova a perícia, a confissão, a declaração do ofendido, o interrogatório, a prova testemunhal, o reconhecimento de pessoas e coisas e a acareação, dentre

11 Para um aprofundamento do conceito de prova e suas respectivas dimensões epistemológica, normativa e interpretativa, ver: MATIDA, 2009. 
outras. Embora não exista predileção em abstrato por qualquer um deles pelo sistema de justiça, nos casos de processos oriundos de abordagens policiais com resultado morte, a prova pericial e a testemunhal aparecem como as mais significativas, pois, diferentemente de crimes de outra natureza, os homicídios dolosos praticados por policial militar contra civil constituem uma conduta de autoria conhecida, cujos efeitos se materializam numa vítima fatal, ou seja, numa conduta que deixa vestígios (FERREIRA, 2017; FERRAZ, 2019).

Mas, ao contrário do que se pode imaginar, a prova não determina tudo no processo criminal, seu efeito nos fluxos processuais de responsabilização depende não só do conteúdo por esta aportado, mas também de quem o avalia, interpreta, pondera, ou ignora, e das regras para que os resultados dessas ações sejam institucionalmente legítimos. Especificamente nos processos relativos a homicídios dolosos praticados por policiais militares contra cidadãos, o arranjo institucional, que conta com julgadores híbridos (juízes togados e leigos) e um conjunto de regras que confere ampla discricionariedade aos jurados, atribui, estruturalmente, à prova três atributos, são eles: a "incerteza intrínseca", a "hierarquia velada" e uma "falsa dualidade incontornável", elementos que serão explorados na próxima subseção, a partir da literatura jurídica estrangeira.

\subsection{DA OPACIDADE DO PENAL ÀS AMBIGUIDADES DO PAPEL DA PROVA}

Em 1998, os juristas Françoise Tulkens e Michel Van de Kerchove, ao analisarem a reforma institucional pela qual passou a Bélgica em 1993, propuseram compreender teoricamente o Direito Penal e suas representações para si mesmo. Ao fazê-lo, se depararam com a questão da "opacidade 12 " do penal, tema que, embora já não fosse recente naquela época, demandava um aprofundamento das suas fontes e origens.

12 Originalmente, os autores utilizam a expressam flou, para fazer referência à vagueza e à imprecisão que aparentam ser inerentes ao ramo direito penal. Escolhi traduzi-la como “opacidade" por entender que as questões levantadas pelos juristas também alcançam uma dimensão de ausência de clareza, de algo que não é translúcido ou do que não é facilmente inteligível. 
Os autores concluíram que a opacidade do direito penal se deve, por um lado, ao fato que a realidade muda e é transformada, isto é, o objeto do direito penal se movimenta; e por outro lado, o olhar que observa as alterações na realidade, também se movimenta e evolui. Assim, do ponto de vista prático, haveria, tanto deslocamentos do objeto, quanto deslocamentos por parte do sujeito que observa as normas penais.

Quanto ao primeiro aspecto, Tulkens e Van de Kerchove (1989), ao historicizarem as mudanças no processo de codificação do direito penal, demonstraram que quando uma nova noção de legalidade se sobrepõe à anterior, a opacidade é o próprio caminho aberto para o reconhecimento do múltiplo. Neste sentido, a codificação do direito penal belga teria caminhado no sentido oposto ao que se espera tradicionalmente de uma reforma do código penal, isto é, tornar as coisas simples, claras e comunicáveis.

Segundo os autores, a persistência da opacidade do direito penal após as alterações do código penal belga se deve a vários fatores, no plano dos deslocamentos do objeto, como por exemplo, à erosão do princípio da legalidade em virtude do fato de outras autoridades que não o Poder Legislativo terem atribuições mais ou menos extensas em matéria penal; às alterações nas funções da pena, que cumprem cada vez mais função reparadora, simbólica e instrumental; às mudanças nas fronteiras que separam a sanção penal da sanção administrativa; e às perturbações no alcance do sistema de justiça penal por conta da construção da União Europeia, cujo surgimento tensionou o equilíbrio das produções normativas Estatais.

Já no que diz respeito ao segundo aspecto, isto é, às mudanças operadas pelo olhar do próprio observador, da realidade que se altera, os autores buscam inspiração em Edgar Morin e se propõem ler "a complexidade do real sob a simples aparência dos fenômenos"13 (TULKENS; VAN DE KERCHOVE, 1989, p. 137). Ao fazer este exercício, os juristas reencontram a opacidade do direito penal, nos deslocamentos operados pelo sujeito - aquele que produz conhecimento sobre e/ou a partir do No original: "l'objectif de lire la complexité du réel sous l'apparence simple des
phénomènes". 
direito penal - dentro de três dimensões: na "incerteza", na "recursividade" e na "dialética".

Na primeira dimensão está a "incerteza”, cujos esforços de eliminação formaram o primeiro ideal do pensamento clássico científico e de dogmática penal em particular. Segundo os autores, nesta dimensão se observa como o direito penal deixou de ser apreendido de forma homogênea - a partir da ideia de que seus contornos eram suficientemente claros para poder identificá-lo com certeza e distingui-lo claramente na comparação com outros ramos do direito - para ser contemplado de forma heterogênea, na qual os contornos do direito penal são mais incertos em comparação com outras formas de normatividades jurídicas.

Nesta outra perspectiva de compreender o direito penal, as contribuições de Herbert Hart seriam cruciais, pois o referido autor teria promovido uma mudança de paradigma ao propor que o direito é afetado por uma "textura aberta irredutível". Neste contexto, teríamos os "casos-padrão", que se enquadram claramente no âmbito dos conceitos penais e correspondem ao que pode ser considerado como a "noção de referência" ou o "paradigma do direito penal”, mas há também situações, condutas e ações que não se encaixam perfeitamente nas formulações jurídico-penais. Por isso, pode se concluir que a linguagem constitui uma fonte inevitável de incerteza relativa às fronteiras do fenômeno (TULKENS; VAN DE KERCHOVE, 1989, p. 138).

Na segunda dimensão ${ }^{14}$ está a "recursividade", ou as "hierarquias invertidas” na expressão de Mireille Delmas-Marty. Ao contrário das hierarquias puras que estabelecem relações exclusivas e contínuas de subordinação entre os vários níveis de um mesmo sistema, as "hierarquias invertidas" se caracterizam pelo fenômeno paradoxal de violação de níveis por elementos que supostamente ocupam nível hierarquicamente inferior, e que passam a exercer, de maneira recursiva, preeminência efetiva sobre os elementos que supostamente ocupam nível superior.

14 Para se referir a esta dimensão os autores utilizam três expressões apresentadas como sinônimas: "récursivité", "hiérarchies enchevêtrées", de autoria de Douglas Hofstadter, e "hiérarchie inversées", de autoria de Mireille Delmas-Marty. 
Além do clássico exemplo de recursividade, observado nas relações e nos limites entre a Convenção Europeia de Direitos Humanos e o direito penal de diferentes Estados-membro da União Europeia, os juristas também ilustram o fenômeno com a evolução do poder discricionário do Ministério Público em matéria de acusação. Segundo os autores, o princípio da oportunidade das acusações se desenvolveu historicamente, desde o início, tanto na França como na Bélgica, por iniciativa do próprio Ministério Público, em violação das disposições aparentemente contrárias do código de instrução criminal, conduzindo, assim, a uma dupla consequência paradoxal: uma prática consuetudinária prevaleceu sobre as disposições imperativas, e órgãos essenciais que supostamente contribuem para a aplicação efetiva da lei receberam o poder de decidir sobre a conveniência de suas ações.

Por fim, a última dimensão proposta pelos autores para observar os deslocamentos operados pelo sujeito é a dialética. Segundo os autores, a terceira dimensão está no reconhecimento de relações dialéticas entre polos que o pensamento clássico apresenta tradicionalmente como radicalmente opostos e dissociáveis, a exemplo da separação drástica entre direito público e direito privado. Ao contrário desta concepção clássica que tradicionalmente propõe perspectivas dualistas, a concepção dialética construída pelos autores admite a relatividade de critérios tradicionais de distinção e enfoca nas múltiplas interações que unem ou aproximam extremidades (TULKENS; VAN DE KERCHOVE, 1989, p. 137-141).

Assim, nesta dimensão, é possível observar que nas últimas décadas houve especial atenção às interações entre elementos tradicionalmente observados como antagônicos. São citados como exemplos, pelos autores, as interações entre as maneiras de proteger interesses públicos e a proteção dos interesses privados amparada pelo direito civil, de modo que se pode reconhecer que uma não está totalmente dissociada da outra; ou ainda, reconhecer que as sanções penais, apesar de sua dimensão repressiva ou retributiva, nunca foram, seja por sua natureza seja por sua função, alheias a qualquer ideia de reparação.

Concluem os autores, "se não podemos minimizar a importância das mudanças ocorridas no fenômeno penal para explicar a imprecisão que o afeta hoje, também não podemos ignorar a importância das mudanças ocorridas nos paradigmas à luz dos quais o fenômeno foi 
estudado"15, e acrescentam, "as representações, por mais teóricas que sejam, que se tem da realidade nunca são sem influência na evolução da própria realidade"16 (TULKENS; VAN DE KERCHOVE, 1989, p. 41).

Embora as categorias utilizadas pelos juristas tenham sido construídas a partir de uma questão de caráter geral, referida a todo um ramo do direito, as categorias propostas são úteis no artigo em tela para uma análise aprofundada da prova e de sua valoração especificamente em processos de homicídios dolosos praticados por policial militar contra civil. Por isso, na próxima seção recuperam-se os conceitos desenvolvidos pelos juristas belgas para complexificar a leitura jurídica sobre o que constitui prova quando a polícia mata. Como se verá, não se trata de mera transposição dos conceitos, mas de um exercício teórico de utilização nova de categorias pensadas originalmente para nomear outros recortes da realidade.

A análise dos materiais que a literatura especializada (CANO; FRAGOSO, 2000; MACHADO, MACHADO, 2015; FERREIRA, 2019) tem indicado como constituintes de prova em processos de homicídios dolosos praticados por policial militar contra civil sinaliza a existência de uma "ambiguidade estrutural" conferida à prova pelo desenho institucional adotado pelo Brasil, que se configura em: (i) incerteza intrínseca; (ii) hierarquia velada; e numa (iii) incontornável falsa dualidade, características da prova que serão melhor desenvolvidas no próximo item, que aprofundará o estudo da prova - instituto de Direito Processual Penal - desde uma perspectiva empírica, inspirada nos aportes teóricos de juristas que as construíram originalmente para olhar para o Direito Penal.

Assim, na próxima seção revisita-se o fluxo processual de responsabilização da polícia que mata para a aferição das implicações desses atributos em cada uma das fases da responsabilização criminal e que potencializam desfechos não-responsabilizantes.

15 No original, "si l'on ne peut minimiser l'importance des bougés intervenus dans le phénoméne pénal pour expliquer le flou qui l'affecte aujourd'hui, on ne peut ignorer non plus l'importance des changements intervenus dans les paradigmes à la lumière desquels ce phénoméne eté étudié".

16 No original: "les représentations, aussi théoriques soient-elles, que l'on se fait de Ia réalité ne sont jamais sans influence sur l'évolution de Ia réalité elle-même (...)". 


\section{Os ATRIBUTOS DA PROVA QUANDO A POLÍCIA MATA AO LONGO DO FLUXO PROCESSUAL}

As abordagens policiais com resultado morte seguem, em regra, um fluxo processual de responsabilização na esfera criminal, que pode ser sinteticamente descrito da seguinte forma, com suas respectivas fases: a fase 1 é constituída pela própria abordagem policial, que embora inacessível do ponto de vista concreto, uma vez que, via de regra, apenas os policiais envolvidos na ocorrência e as vítimas fatais vivenciaram a situação, é neste momento que as eventuais situações-problemas que conformam crimes ocorrem, sendo as mais comuns "fraude processual", "resistência" e "homicídio doloso". É nesta fase também que os insumos de eventual investigação são produzidos; a fase 2 é a investigação propriamente dita. A atividade de apuração dos fatos pelas agências de controle, tanto na Polícia Civil, quanto na Polícia Militar, está ancorada essencialmente nos elementos informativos extraídos do que é constatado visualmente no local dos fatos, do que é dito pelas testemunhas que presenciaram os fatos, e do que é escrito pelos responsáveis pela apuração e responsabilização dos policiais militares; na fase 3 ocorre o julgamento, respeitadas as subfases: recebimento da denúncia; sentença de pronúncia; decisão do Conselho de Sentença; em seguida, na fase 4, um/a juiz/a togado/a produzirá uma sentença, em função da decisão do Conselho de Sentença, momento no qual, declarará a absolvição do réu ou o condenará, com o respectivo cálculo da pena, é a chamada fase sancionatória; e, por fim, a depender do conteúdo da sentença, poderá haver uma fase de implementação da sanção ${ }^{17}$.

A análise atenta de cada uma destas fases permite verificar as implicações que a prova traz para o processo e a forma como desfechos não-responsabilizantes são construídos e legitimados. Os esforços registrados nas subseções que seguem nos ajudam a compreender como, mesmo em um caso no qual um policial implicado diretamente na morte de um civil, em contexto de abordagem, confessa a prática de homicídio doloso porque estava com raiva do suspeito, e é absolvido

\footnotetext{
17 Essas fases estão cuidadosamente descritas em: FERREIRA, 2019.
} 
da acusação após percorridas todas as fases do fluxo processual de responsabilização descrito acima ${ }^{18}$.

Nos próximos itens, examina-se cada um dos atributos que conferem à prova, neste tipo específico de ocorrência, uma ambiguidade estrutural.

\subsection{A INCERTEZA INTRÍNSECA (E INSTITUCIONALIZADA) SOBRE OS FATOS}

O que realmente motivou a abordagem policial que resultou em morte? como e com quais critérios os policiais militares intervieram verbal e fisicamente no contexto de abordagem? quais foram as circunstâncias que autorizaram policiais militares a atirarem? Onde e por que atiraram? Essas são algumas das questões que prendem a atenção de quem se propõe a acompanhar júris de policiais militares na justiça criminal.

É muito provável que nem mesmo quem tenha acompanhado a ação tenha clareza sobre as respostas ou consiga reconstruir uma narrativa fidedigna em plenário. As pessoas que acompanharam, na condição de vítima, de autor ou de testemunha estão de tal forma implicados nos fatos ou nas suas consequências, que o acesso cognitivo preciso à abordagem policial que resultou em morte é, definitivamente, inviável.

Essa impossibilidade de acessar a abordagem policial que resultou em morte, com a finalidade de julgar os implicados na ação, constitui uma fonte de incerteza nos processos de apuração dos fatos.

No Brasil, embora os policiais militares integrem a organização dos estados e tenham atribuições determinadas na Constituição e em normas específicas, os efeitos do trabalho policial ainda não foram totalmente parametrizados e fiscalizados pelo próprio Estado. Com exceção das consequências que tem reversão monetária - a exemplo dos índices de produtividade baseados em prisões em flagrante ou em apreensão de drogas e armas - ainda são poucas as medidas que busquem enfrentar a letalidade e a vitimização policial.

Como decorrência disso, são limitados os números de instituições policiais que elaboraram protocolos de controle do uso da força e são

18 Caso real que foi objeto de estudo em: FERREIRA, 2019. 
quase inexistentes as polícias que produziram procedimentos operacionais padrão em diálogo com a sociedade civil, se colocando, inclusive, à disposição desta para tratar problemas estruturais de dentro e de fora da corporação, como por exemplo, as relações entre racismo e os limites da "fundada suspeita" nas operações policiais.

O efeito dessas escolhas não pode ser desconsiderado na análise da maneira segundo a qual o Estado responsabiliza criminalmente policiais militares. No caso específico de São Paulo, chama a atenção, ainda, a ausência de equipamentos que permitiriam ou facilitariam o acesso à atuação dos policiais em local e hora específicos, da mesma forma que a ausência de informações públicas a respeito de como esta deveria ocorrer, acessível à sociedade civil, também se faz notar (FERREIRA, 2019).

Sobre os equipamentos de registro das ações policiais, até a data da abordagem policial que deu origem ao estudo aqui mencionado, $1^{\circ} \mathrm{de}$ janeiro de 2015, ainda não havia um programa de utilização de câmeras de vigilância acopladas em viaturas ou em uniformes dos policiais militares.

Em julho de 2020, o governo do Estado de São Paulo anunciou o Programa "Olho Vivo", cujo objetivo é aprimorar a prestação de serviço de segurança pública a partir da utilização de câmeras que pudessem manter o registro audiovisual da atuação policial. Segundo a Polícia Militar, a "Câmera Operacional Portátil (COP) é um equipamento de gravação de vídeo acoplado ao uniforme do policial militar utilizado para gravar as ações policiais qualificando as provas produzidas pela Polícia Militar” (PMSP, 2020, p. 01).

Entre as vantagens enumeradas pela própria Polícia Militar está o fato que o equipamento contribuiria para a transparência e legitimidade das ações policiais", o "fortalecimento da prova judicial", a "redução do uso da força”, dentre outras (PMSP, 2020a, p. 01). O projeto básico vinculado ao procedimento licitatório instaurado pela Diretoria de Tecnologia da Informação e Comunicação da Polícia Militar busca a contratação de "solução integrada de prestação de serviço de captação, armazenamento, transmissão, custódia e gestão de evidências digitais por câmeras operacionais portáteis" (PMSP, 2020b, p. 39), o que incluiria, também, o fornecimento dos equipamentos necessários para o estabelecimento de links com o sistema de armazenamento em nuvem, além dos recursos tecnológicos necessários para acionamento remoto 
das câmeras operacionais portáveis e a transmissão por livestreaming para o Centro de Operações da Polícia Militar do Estado de São Paulo (PMSP, 2020b).

Mesmo que ainda em fase incipiente, a iniciativa é um avanço significativo em relação ao desenvolvimento de procedimentos de accountability horizontal, na medida em que, proporciona maior transparência e facilita a prestação de contas do uso da força pública no estado de São Paulo, sugerindo a possibilidade de redução da incerteza na reconstituição dos fatos, sem que essa seja anulada.

Do ponto de vista processual penal, gravações oriundas de câmeras operacionais portáteis não determinam desfechos jurídicos, pois quando ingressam como prova no processo demandam interpretações junto a normas constitucionais, processuais e penais, cujos sentidos, quase sempre, não estão afeitos a meras subsunções formais. Como lembra a jurista Caren Morrison, ao aprofundar estudos sobre os efeitos do uso de gravações em casos de violência policial letal em tribunais norte-americanos, "a crença amplamente compartilhada de que um vídeo "provará” que uma ação policial é excessiva muitas vezes afundará em uma combinação do padrão legal e da estrutura narrativa dominante"19 (MORRISON, 2017, p. 801), ou seja, a crença de que o material audiovisual traz em si uma realidade objetiva, paradoxalmente, limita as potencialidades de sua utilização pelos atores jurídicos ou, inevitavelmente, produz resultados inesperados, surpreendentes, incoerentes, tendo em vista que, no campo do direito, e não só nele, a realidade está sempre sujeita à interpretação.

Assim, a leitura da gravação da violência policial letal está subordinada a uma ampla rede de códigos e sentidos, que podem ou não corresponder àqueles construídos pelo "senso comum", elemento institucionalmente valorizado no júri, instância escolhida no Brasil para lidar com casos provenientes da letalidade policial.

Mesmo assim, diante do atual contexto de opacidade institucional da Polícia Militar em relação à atividade de policiamento ostensivo,

19 Na versão original: "The widely shared belief that a video will "prove" a police action to be excessive will often founder on a combination of the legal standard and the dominant narrative framework". 
eventuais filmagens podem possibilitar que percepções de legitimidade da ação policial possam ser moldadas e novos parâmetros de responsabilização a essa podem ser reconfigurados na sociedade civil (MEARES; TYLER; GARDENER, 2015).

Vale ressaltar que, no que concerne à ausência de informações públicas a respeito dos protocolos da atuação policial, os procedimentos operacionais padrão da Polícia Militar de São Paulo encontram-se sob sigilo, na modalidade secreto, desde 2013, em função de Portaria do Comandante Geral. O referido documento alterou o grau de publicidade dos protocolos de atuação policial em circunstância de "Abordagem de Pessoa(s) a Pé” e "Abordagem policial com viatura '4 rodas', dentre outras. A medida contribuiu para a opacidade da instituição, pois inviabiliza o acesso público à maneira segundo a qual a força pública se autoriza (e se auto-orienta) a limitar direitos fundamentais do cidadão comum, ficando esta sem qualquer controle social. A portaria também produz, como impacto indireto, mais um meio de desrespeitar os princípios básicos da lei de acesso à informação, e um desincentivo à formação do cidadão comum, inclusive aquele que se tornará potencial julgador de policiais que matam em serviço

\subsection{As HIERARQUIAS VELADAS}

Na dogmática processual penal, a ideia de que "não há hierarquia entre as provas" é repetida como um mantra. A legislação lhe confere amparo legal no Código de Processo Penal ${ }^{20}$ e no Código de Processo Civil ${ }^{21}$ e a doutrina encontra seu fundamenta na função da prova no processo, qual seja, "a reconstrução da realidade histórica, sobre a qual se

20 Art. 155. "O juiz formará sua convicção pela livre apreciação da prova produzida em contraditório judicial, não podendo fundamentar sua decisão exclusivamente nos elementos informativos colhidos na investigação, ressalvadas as provas cautelares, não repetíveis e antecipadas. Parágrafo único. Somente quanto ao estado das pessoas serão observadas as restrições estabelecidas na lei civil".

21 art. 371 do NCPC, “o juiz apreciará a prova constante dos autos, independentemente do sujeito que a tiver promovido, e indicará na decisão as razões da formação de seu convencimento". 
pronunciará a certeza quanto à verdade dos fatos, para fins de formação da coisa julgada" (PACELLI, 2015, p. 341).

Como lembra Eugênio Pacelli (2015), embora inexista hierarquia entre as provas, é plenamente possível sustentar a "exigência de meios de prova específicos para a constatação de determinados fatos" (PACELLI, 2015, p. 342), a exemplo da determinação do art. 564, III, b, do Código de processo penal no que concerne à exigência de exame do corpo de delito nos crimes que deixam vestígios, que é o caso dos homicídios dolosos praticados por policial militar contra civil. É a chamada regra da especificidade da prova.

Mas o que as pesquisas empíricas têm apontado é que, embora haja produção de documentos públicos sinalizando uso excessivo da força pelo policial, juntado aos autos processuais, persiste a prevalência da versão do policial militar nos processos de responsabilização criminal em casos de homicídio doloso praticado por policial contra civil, notadamente, em hipóteses onde a principal tese defensiva se ancora na sustentação da existência de excludente de ilicitude.

A versão dos policiais militares sobre os fatos emerge ao longo de todo o processo de responsabilização como uma entidade autônoma, que é capaz de gerar, por si mesma, elementos informativos. Ao mesmo tempo em que se configura como um guia e/ou impulso para as primeiras ações institucionais de registro dos fatos, sem necessariamente haver movimentos de apuração, ela também se mostra viva no conteúdo dos pilares de sustentação dos primeiros movimentos institucionais de apuração e de responsabilização (FERREIRA, 2019).

Depoimentos, testemunhos e interrogatórios (que são também meio de autodefesa) de policiais militares em juízo são constantemente sobrepostos a provas "reais" 22 , fotografias, ferimentos, as balas e as imagens do corpo perfurado, que são seguidas de laudo de exame cadavérico, o qual, não raro, indica que os tiros foram disparados em regiões fatais e à curta distância (MISSE; GRILLO; NERI, 2015; CRISTOVÃO, 2015), documentos que não são lidos pelos jurados durante a dinâmica na qual se desenvolvem os julgamentos em plenário.

22 Construção doutrinária que classifica as provas que emergem do fato (TÁVORA; ALENCAR, 2009). 
Do ponto de vista estrutural, a prova oriunda da palavra dos policiais implicados, notadamente o interrogatório, tem o poder de nulificar a versão das vítimas e determinar a absolvição do réu ainda que tenha ficado provado por outros meios a culpa do PM, hipótese na qual os jurados decidem perdoá-lo e absolvê-lo, ainda que por decisão manifestamente contrária à prova dos autos, na chamada clemência, que é uma construção doutrinária para o reconhecimento da retirada deliberada de eventual punição por parte dos jurados. Como lembra Diogo Erthal Costa,

a clemência, considerada como fundamento da absolvição de réu no tribunal do júri, deve ser compreendida como ato judicial colegiado, pois manifestação do conselho de sentença, de efeitos individuais, já que incide apenas sobre aquele em relação ao qual se formulou o quesito genérico, mediante o qual os jurados, apesar de reconhecerem previamente a prática de ato típico, ilícito e culpável pelo acusado, o absolvem em ato de benevolência que dispensa qualquer motivação específica, impedindo a aplicação de sanção de natureza penal. Investidos na função de julgadores, portanto, representantes do Estado-juiz, os jurados manifestariam imotivada dispensa estatal à punição (COSTA, 2019, p. 50-51).

Nessa ocasião, independente do quanto foi produzido institucionalmente, não só o “juiz-presidente” estará "governado pelo júri”, mas o próprio Tribunal de Justiça também poderá reger suas ações em função dessa decisão do conselho de sentença, sinalizando que a depender da fonte da qual emerge a prova - laudo de exame cadavérico, testemunho de policiais, testemunho dos familiares da vítima, por exemplo - o valor conferido pelos atores processuais que operacionalizam o desenho institucional é diferente, quiçá, hierarquicamente desigual.

A narrativa dos policiais é, assim, novamente considerada como um fator que tem um peso determinado, inclusive por instância hierarquicamente superior, ganhando ainda mais força em grau de recurso quando se sustenta na defesa e na proteção do "princípio constitucional da soberania dos vereditos".

As "hierarquias invertidas" apresentadas por Tulkens e Van de Kerchove (1989), são, assim, reencontradas no contexto estudado 
na hierarquização velada dos meios de prova, cuja consequência são as absolvições em plenário do júri, que se dão, de maneira geral, alheias às provas reais - já que os jurados não leem os documentos que compõem os autos processuais.

\subsection{FALSA DUALIDADE INCONTORNÁVEL}

Não é qualquer pessoa que pode produzir provas. Nos processos de responsabilização de homicídios dolosos, acusação e defesa devem produzir os meios de provar suas alegações. Embora o Ministério Público detenha o ônus de "provar a existência do fato criminoso, da sua realização pelo acusado e também a prova dos elementos subjetivos do crime (dolo ou culpa)"; cabe ao acusado provar, por exemplo, que ocorreu legítima defesa.

Esse desenho tem levado a uma série de divisões e rivalidades que não favorecem o aproveitamento de materiais produzidos por diferentes instituições. Descartes de documentos, narrativas de pessoas não arroladas como testemunhas porque "não interessa" à versão da acusação, ou à versão da defesa, ausência de testemunhas-chave que de última hora não comparecem e não são compelidas a irem por razões de produtividade profissional dos operadores do direito que atuam no respectivo processo, impedem que a sociedade civil conheça conteúdos que são produzidos ao longo do processo criminal.

Esse dualismo, típico do processo criminal, cujos efeitos se fazem sentir numa produção probatória concorrencial - acusação versus defesa, policial versus vítima, e em alguns casos, Polícia versus policial também atrela à prova um falso papel de esclarecer os fatos e impede a total cooperação das agências de controle social penal que atuam nos processos. Afinal, embora um volume imenso de informações seja produzido rotineiramente e circule por diferentes instituições e esferas do direito, o Brasil ainda não produz (ou divulga) informações públicas sistemáticas a respeito do uso da força pelas polícias e de seus efeitos sobre a democracia, sobre o Estado de Direito.

Esse falso dualismo escamoteia o fato que a polícia brasileira é a que mais morre, mais mata e mais se suicida, no mundo; o fato que a maioria das vítimas são negras, estando elas fardadas ou não, e por 
fim, o fato que o atual desenho institucional não dá conta da responsabilização dos agentes públicos que matam em serviço, tampouco da reparação às vítimas e aos seus familiares, ou a quaisquer respostas à sociedade civil e aos movimentos sociais a respeito da matança autorizada pelo Estado.

\section{Considerações finaIs}

O que se sabe a respeito da forma como o Estado escolheu responsabilizar policiais militares implicados em abordagens policiais que resultaram em morte? Como desfechos não-responsabilizantes são construídos? O que constitui e o que significa provar em processos de homicídios dolosos praticados por policial militar contra civil?

Um mergulho profundo nas águas turvas do penal, esfera de atuação estatal que costuma ser demandada por importantes setores da sociedade civil como campo preferencial para punir agentes públicos de segurança implicados na morte de cidadãos, apontou para a ausência de responsabilização dos réus ${ }^{23}$. Embora parcamente transparente e com

${ }^{23}$ Cabe sublinhar neste ponto a recente estratégia da sociedade civil organizada de utilização do Supremo Tribunal Federal como mais uma instância capaz de atuar, ainda que indiretamente, na contenção da letalidade policial, através do julgamento da Ação de Descumprimento de Preceito Fundamental n. 635, em que se pleiteia a adoção de medidas para a redução da letalidade policial no Rio de Janeiro. Mais que um caminho estritamente jurídico para resolver o problema, a atuação do STF neste tema tem sinalizado (i) o comprometimento político da Corte com a proteção de direitos fundamentais de minorias políticas (população negra e periférica), fundamental pilar de uma democracia constitucional; (ii) que a atuação das instituições jurídicas tem relevância para o enfrentamento de desigualdades estruturais e (iii)a redução da letalidade policial pode ser uma realidade desde que haja comprometimento da sociedade civil e do Estado, ainda que através de decisões cautelares, como aquela que determinou a suspensão de operações policiais durante o período da pandemia de covid-19, salvo exceções ali expressas e aquela que concedeu acesso às comunicações das operações policiais, assim como aos relatórios produzidos ao final das operações, em resposta ao sigilo imposto por autoridades do Estado do Rio de Janeiro em relação às informações sobre as operações policiais ocorridas após a concessão da cautelar que restringiu as operações, notadamente às investigações das mortes produzidas no âmbito da chacina do Jacarezinho, em maio de 2021 , que veio a se tornar a operação 
respostas pouco uniformes no tratamento conferido ao ato de matar alguém, há definitivamente uma agenda de pesquisa a ser explorada no que diz respeito ao estudo da letalidade policial e de suas relações com a justiça criminal.

Através da revisão de literatura, contatou-se que os estudos realizados no âmbito do Direito, embora contributivos para pensar o problema abstratamente, pouco avançaram empiricamente na compreensão do papel da prova nestes tipos de processos.

O diálogo com os aportes teóricos desenvolvidos pelos juristas belgas, Françoise Tulkens e Michel Van de Kerchove (1998), permitiram uma leitura original do papel da prova nos processos de homicídios dolosos praticados por policial militar contra civil. Constatou-se que o desenho institucional escolhido pelo Brasil confere à prova uma ambiguidade estrutural nesse tipo de processo criminal.

Neste sentido, ao mesmo tempo em que a prova funciona como um mecanismo contra arbitrariedades eventualmente promovidas pelo/a magistrado/a ou pelo/a promotor/a, é a prova também que viabiliza que as sanções penais previstas abstratamente para casos de violência policial letal se tornem inócuas. Essa ambiguidade estrutural se mantém graças à incerteza inerente aos fatos, às hierarquias veladas produzidas institucionalmente e à incontornável falsa dicotomia que produz leituras incompletas e imprecisas, dentro e fora dos processos judiciais.

A incerteza inerente aos fatos no momento da abordagem policial está protegida institucionalmente pela escolha da polícia militar em não produzir meios de registrar em áudio e vídeo as abordagens, assim como, na ausência de protocolos públicos de intervenção da polícia que instrumentalize e qualifique as pessoas - cidadãos e potenciais julgadores - a respeito do que constitui os limites da polícia dentro de um Estado Democrático de Direito.

As "hierarquias veladas" que se constroem institucionalmente dentro dos processos, seja na valorização de provas oriundas da palavra dos

policial mais letal da história do Rio de Janeiro (SUPREMO TRIBUNAL FEDERAL, Arguição de Descumprimento de Preceito Fundamental 635 Rio de Janeiro, Relatoria de Edson Fachin, decisões datadas de 05 de agosto de 2020 e de 30 de junho de 2021, respectivamente). 
policiais, especialmente, quando estes sustentam a existência de legítima defesa, seja do poder que é conferido a essas narrativas mesmo em instâncias superiores dentro do tribunal de justiça, demonstrando, inclusive que o poder discricionário conferido à polícia militar no desenvolvimento de suas atribuições tem repercussão fora da sua arena de trabalho.

E, por fim, o incontornável falso dualismo que separa o mundo em apenas duas perspectivas opostas e que tem inviabilizado leituras sistêmicas sobre as relações entre atores jurídico-processuais cruciais, os pontos de convergência entre estes, e a elaboração de um balanço sobre as falhas na responsabilização daqueles agentes.

Ao conferir à prova ambiguidade estrutural nos processos de homicídios dolosos praticados por policial militar contra civil, o Brasil institucionaliza a não-responsabilização criminal de policiais como desfecho possível e legítimo dentro do Estado Democrático de Direito.

\section{RefERÊNCIAS BIBLIOGRÁFICAS}

ADORNO, Sérgio; PASINATO, Wânia. A justiça no tempo, o tempo da justiça. Tempo social, 2007, 19.2.

ADORNO, Sergio; PASINATO, Wânia. Violência e impunidade penal: da criminalidade detectada à criminalidade investigada. Dilemas: Revista de Estudos de Conflito e Controle Social, 2010, 3.7: 51-84.

AGUIAR, Cristiane Lamin Souza. Medo e descrença nas instituições de lei e ordem: uma análise da imprensa escrita e das sondagens de opinião. Universidade de São Paulo. Faculdade de Filosofia, Letras e Ciências Humanas - Departamento de Sociologia. Dissertação (mestrado). São Paulo, 2005.

ALMEIDA, Silvio. Racismo estrutural. Belo Horizonte: Editora Letramento, 2018.

ALVES, Jaime Amparo. Topografias da violência: necropoder e governamentalidade espacial em São Paulo. Revista do Departamento de Geografia, 2011, 22: 108-134.

BARROS, Geová da Silva. Filtragem racial: a cor na seleção do suspeito. Revista Brasileira de Segurança Pública, 2008, ano 2, Edição 3, jul/ago. 2008.

BOITEUX, Luciana. Tráfico e Constituição: um estudo sobre a atuação da justiça criminal do Rio de Janeiro e de Brasília no crime de tráfico de drogas. Revista Jurídica da Presidência, v. 11, n. 94, p. 01-29, 2010. 
BRASILEIRO DE LIMA, Renato. Manual de processo penal. Salvador: Editora JusPodivm, 2020.

BUENO, Samira. Bandido bom é bandido morto: a opção ideológico-institucional da política de segurança pública na manutenção de padrões de atuação violentos da polícia militar paulista. Dissertação (Mestrado) - Fundação Getúlio Vargas, Escola de Administração de Empresas de São Paulo, 2014, p. 122.

CANO, I. Letalidade da ação policial no Rio de Janeiro: a atuação da justiça militar. Rio de Janeiro: ISER, 1999.

CANO, I. Viés racial no uso da força letal pela polícia no Brasil. MPMG Jurídico, 2014 , n. 1 , p. $17-25$.

CANO, Ignácio; FRAGOSO, José Carlos Fragoso. Letalidade da ação policial no Rio de Janeiro: a atuação da justiça militar. Revista Brasileira de Ciências Criminais. Ano 8, n. 30, abril-junho, 2000.

CARDOSO, Renata Valéria Pinto; RAMOS, Edson Marcos Leal Soares. Caracterização do crime de tráfico de drogas a partir das sentenças condenatórias da Vara de combate ao crime organizado de Belém-PA. Research, Society and Development, 2020, 9.11: e989119621-e989119621.

COMPARATO, Bruno Konder. As ouvidorias de polícia no Brasil: controle e participação. 262f. 2005. Tese de doutorado - Faculdade de Filosofia, Letras e Ciências Humanas, Universidade de São Paulo, São Paulo, 2005.

COSTA, Diego Erthal Alves da. A Clemência no Tribunal do Júri no Brasil. Revista do Ministério Público do Estado do Rio de Janeiro n. 71, 2019, 71: 49.

CHRISTOVÃO, Nanci Tortoreto. Os 111 laudos necroscópicos do Carandiru: evidências de uma execução. Dissertação (mestrado em direito). São Paulo: Escola de Direito de São Paulo, Fundação Getúlio Vargas, 2015.

DUARTE, Evandro; MURARO, Mariel; LACERDA, Marina; GARCIA, Rafael. Quem é o suspeito do crime de tráfico de drogas? Anotações sobre a dinâmica de preconceitos raciais e sociais na definição das condutas de usuário e traficante pelos policiais militares nas cidades de Brasília, Curitiba e Salvador. LIMA, Cristiane; BAPTISTA, Gustavo; FIGUEIREDO, Isabel S. Segurança Pública e Direitos Humanos: temas transversais. Col. Pensando a Segurança Pública, v. 5, Brasília: Ministério da Justiça/Senasp, 2014, p. 81 - 118.

DINAMARCO, Cândido Rangel. Instituições de Direito Processual Civil. São Paulo: Malheiros, 2001. 
FBSP. FÓRUM BRASILEIRO DE SEGURANÇA PÚBLICA. Anuário brasileiro de Segurança Pública. Ano 11. São Paulo: Fórum Brasileiro de Segurança Pública, 2017.

FBSP. FÓRUM BRASILEIRO DE SEGURANÇA PÚBLICA. Anuário brasileiro de Segurança Pública. Ano 15. São Paulo: Fórum Brasileiro de Segurança Pública, 2021.

FERRAZ, Taís Schilling. Articulação e comunicação entre os agentes do Estado: possíveis impactos sobre a impunidade nos crimes de homicídio. Revista da AJURIS, 2019, 45.145: p. 267-292.

FERREIRA, João Henrique, et al. Indícios, presunções e ficções no direito penal: aspectos principais. 2006. 420f. Dissertação (mestrado em Direito Penal). Pontificia Universidade Católica. São Paulo, 2006.

FERREIRA, Poliana da Silva. Prendendo quem captura: a prisão de policiais militares em casos de homicídios dolosos contra civis em São Paulo. Anais do III Seminário Internacional de Pesquisa em Prisão. GT15 - Discursos sobre a privação de liberdade e a prisão: análise das maneiras de dizer/fazer as políticas públicas para condutas criminalizadas. Universidade Federal de Pernambuco, Recife, 2017.

FERREIRA, Poliana da Silva. A responsabilização da polícia que mata: um estudo de caso sobre o tratamento jurídico das abordagens policiais com resultado morte. Dissertação (mestrado em direito). São Paulo: Escola de Direito de São Paulo, Fundação Getúlio Vargas, 2019, p. 146.

FERREIRA, Poliana da Silva. Entre os quatro poderes: quadros normativos, conflitos institucionais e outros obstáculos à responsabilização da polícia que mata. In.: MACHADO, Maíra Rocha. Justiça criminal entre poderes. São Paulo: FGV Direito SP, 2020.

FERREIRA, Poliana da Silva. Justiça e letalidade policial: responsabilização jurídica e imunização da polícia que mata. Coleção Justiça Plural. São Paulo: Jandaíra, 2021.

FERREIRA, Poliana da Silva. Entre o indissociável e o inacessível: o que nos ensinam os estudos sobre justiça criminal e desigualdade racial? Revista Brasileira de Ciências Criminais, v. 181, ano 29, p. 163-193, São Paulo: Editora RT, Julho, 2021.

FERREIRA, Poliana da Silva. Unindo pontas soltas: racismo institucional, letalidade policial e sistema de justiça, Revista Videre, 2021, no prelo.

FLAUZINA, Ana Luiza Pinheiro. Corpo negro caído no chão: o sistema penal e o projeto genocida do Estado brasileiro. 2006. 145 f. 2006. Dissertação (Mestrado em Direito), Universidade de Brasília, Brasília, 2006. 
GOMES, Letícia Pereira Simões. A (in)visibilidade da questão racial na formação dos soldados da Polícia Militar. 2018. Dissertação (Mestrado em Sociologia) - Faculdade de Filosofia, Letras e Ciências Humanas, Universidade de São Paulo, São Paulo, 2018. http://doi.org/10.11606/D.8.2019.tde-20032019-101356

GOMES, Luis Flávio. A impunidade no Brasil: de quem é a culpa?: esboço de um decálogo dos filtros na impunidade. Centro de Estudos Judiciários, Brasília, n. $15,2001$.

HOWLETT, Michael. A dialética da opinião pública: efeitos recíprocos da política pública e da opinião pública em sociedades democráticas contemporâneas. Opin. Publica, Campinas, v. 6, n. 2, p. 167-186, Oct. 2000. https://doi.org/10.1590/ S0104-62762000000200001

JONES, Camara Phyllis. Confronting institutionalized racism. Phylon (1960-), v. 50, n. 1/2, Clark Atlanta University, 2002.

MACHADO, Bruno Amaral. Duas “leituras” sobre a construção jurídica da impunidade. Revista de informação legislativa, 2006, 171: p. 279.

MACHADO, Maíra; MACHADO, Marta. Carandiru não é coisa do passado: um balanço sobre os processos, as instituições e as narrativas 23 anos depois. São Paulo: FGV Direito, 2015, p. 21.

MACHADO, Maíra; MACHADO, Marta.; FERREIRA, Carolina Cutrupi. 20 anos do massacre do Carandiru. Disponível em: https://direitosp.fgv.br/ pesquisa/20-anos-massacre-carandiru.

MATIDA, Janaína. O problema da verdade no processo: a relação entre fato e prova. 2009. 112f. Dissertação (Mestrado em Direito), Pontifícia Universidade Católica do Rio de Janeiro, Rio de Janeiro, 2009.

MATIDA, Janaina; HERDY, Rachel. As inferências probatórias: compromissos epistêmicos, normativos e interpretativos1. Revista do Ministério Público do Estado do Rio de Janeiro n ${ }^{\circ}, 2019$, p. 73-133.

MARTINS, Rui Cunha. Estado de Direito, evidência e processo: incompatibilidades electivas. Duc In Altum: Cadernos de Direito, v. 3, n. 3, 2011.

MEARES, Tracey L.; TYLER, Tom R.; GARDENER, Jacob. Lawful Or Fair-How Cops and Laypeople Perceive Good Policing. J. Crim. L. \& Criminology, 2015, v. 105, n. 297. 
MINGARDI, Guaracy. A Investigação de Homicídios: a construção de um modelo. Relatório final. Concurso de nacional de pesquisas aplicadas em justiça criminal e segurança pública. Brasília: Ministério da Justiça, 2006.

MISSE, Michel (coord). Relatório final de pesquisa “autos de resistência”: uma análise dos homicídios cometidos por policiais na cidade do rio de janeiro (2001-2011). Núcleo de Estudos da Cidadania, Conflito e Violência Urbana Universidade Federal do Rio de Janeiro Edital MCT/CNPq N 14/2009 - Universal. Rio de Janeiro, 2011.

MISSE, Michel; GRILLO, Carolina Christoph; NERI, Natasha Elbas. Letalidade policial e indiferença legal: a apuração judiciária dos 'autos de resistência' no Rio de Janeiro (2001-2011). Dilemas: Revista de Estudos de Conflito e Controle Social - Edição Especial no 1, 2015, p. 43-71.

MORRISON, Caren Myers. Body Camera Obscura: the semiotics of police video. Am. Crim. L. Rev., 2017, v. 54, n 791.

NEME, Cristina. A Instituição Policial na Ordem Democrática: o caso da Polícia Militar do Estado de São Paulo. Dissertação de mestrado - Departamento de Ciência Política da Faculdade de Filosofia, Letras e Ciências Humanas da Universidade de São Paulo. São Paulo, 1999. p. 94.

NERY, Felipe Souza; NADANOVSKY, Paulo. Homicide impunity in Brazil between 2006 and 2016. Revista de Saúde Pública, 2020, n. 54.

PACELLI, Eugênio. Curso de Processo Penal. São Paulo: Atlas, 2015.

REIS, Vilma Maria. Atucaiados pelo Estado: as políticas de segurança pública implementadas nos bairros populares de Salvador e suas representações, 1991 2001. Dissertação (Mestrado em Sociologia), Faculdade de Filosofia e Ciências Humanas, Universidade Federal da Bahia, Salvador, 2005.

RIBEIRO, Ludmila. Impunidade no sistema de justiça criminal brasileiro: Uma revisão dos estudos produzidos sobre o tema. Latin American and Iberian Institute, University of New Mexico. Research Paper Series, n. 48, August 2009. Disponível em: https://digitalrepository.unm.edu/cgi/viewcontent.cgi?article=1039\&context=laii_research. Acesso 13 jan 2021.

SÃO PAULO. Polícia Militar do Estado de São Paulo. Câmeras operacionais portáteis: segurança e transparência a serviço do cidadão. Folder. Disponível em: https://www.policiamilitar.sp.gov.br/COP/Index\#/regras-de-uso/documentos. Acesso 06 jan. 2021 
SINHORETTO, Jacqueline; SILVESTRE, Giane; SCHLITTLER, Maria Carolina. Desigualdade racial e Segurança pública em São Paulo. Letalidade policial e prisões em flagrante. Ufscar, 2014.

SUDBRACK, Aline Winter. A violência policial e o poder Judiciário: estudo sobre a (i) legitimidade da ação violenta da polícia e a impunidade. Porto Alegre, 2008. 278p. Tese de Doutorado - Instituto de Filosofia e Ciências Humanas, Universidade Federal do Rio Grande do Sul, p. 224.

TULKENS, Françoise; VAN DE KERCHOVE, Michel. D’où viennent les flous du droit pénal? Les déplacements de l'objet et du sujet. In.: CARTUYVELS, Yves; DIGNEFFE, Françoise; PIRES Alvaro; ROBERT, Philippe (Org.). Politique, police et justice au bord du futur. Mélanges pour et avec Lode Van Outrive, coll.«Logiques sociales», Paris: L'Harmattan, 1998.

VARGAS, Joana Domingues. Padrões do estupro no fluxo do sistema de justiça criminal em Campinas, São Paulo. Rev. katálysis, Florianópolis, v. 11, n. 2, p. 177186, Dec. 2008.

VERANI, Sérgio. Assassinatos em Nome da Lei. Rio de Janeiro: Aldebarã, 1996.

ZACCONE, Orlando. Indignos de vida: A forma jurídica da política de extermínio de inimigos na cidade do Rio de Janeiro. Rio de Janeiro: Revan, 2015.

ZAFFALON CARDOSO, L. A política da justiça: Blindar as elites, criminalizar os pobres. São Paulo: Editora Hucitec, 2018. 


\section{Informações adicionais e declarações dos autores (integridade científica)}

Agradecimentos (acknowledgement): Agradeço a atenta e generosa leitura que as versões anteriores deste texto receberam de Marco Aurélio Macedo, Manuela Abath e Maíra Machado. Pesquisa com fomento da Fundação de Amparo à Pesquisa do Estado de São Paulo.

Declaração de conflito de interesses (conflict of interest declaration): a autora confirma que não há conflitos de interesse na realização das pesquisas expostas e na redação deste artigo.

Declaração de autoria e especificação das contribuições (declaration of authorship): todas e somente as pessoas que atendem os requisitos de autoria deste artigo estão listadas como autores; todos os coautores se responsabilizam integralmente por este trabalho em sua totalidade.

Declaração de ineditismo e originalidade (declaration of originality): a autora assegura que o texto aqui publicado não foi divulgado anteriormente em outro meio e que futura republicação somente se realizará com a indicação expressa da referência desta publicação original; também atesta que não há plágio de terceiros ou autoplágio.

\section{Editorial process dates}

(http://www.ibraspp.com.br/revista/index.php/RBDPP/about/editorialPolicies)

- Submission: 25/06/2021

- Desk review and plagiarism check:

- Review 1: 04/07/2021

- Review 2: 29/07/2021

- Review 3: 04/08/2021

- Preliminary editorial decision: 09/08/2021

- Correction round return: $23 / 08 / 2021$

- Final editorial decision: 15/09/2021
Editorial team

- Editor-in-chief: 1 (VGV)

- Associated-editor: 1 (MAV)

- Reviewers: 3 


\section{HOW TO CITE (ABNT BRAZIL):}

FERREIRA, Poliana da Silva. "Nas águas turvas do penal": os fatos e a prova nos processos de responsabilização em casos de letalidade policial. Revista Brasileira de Direito Processual Penal, vol. 7, n. 3, p. 22452282, set./dez. 2021. https://doi.org/10.22197/rbdpp.v7i3.582 